\title{
Steers production in integrated crop-livestock systems: pasture management under different sward heights ${ }^{1}$
}

\author{
Produção de novilhos em sistemas integrados de produção agropecuária: manejo do \\ pasto sob diferentes alturas
}

\author{
Cristiane de Lima Wesp ${ }^{2 *}$, Paulo César de Faccio Carvalho ${ }^{3}$, Osmar Conte ${ }^{4}$, Mónica Cadenazzi ${ }^{5}$, Ibanor \\ Anghinoni $^{6}$ e Carolina Bremm ${ }^{7}$
}

\begin{abstract}
The aim of this study was to evaluate the effects of different grazing intensities on forage production and animal performance of yearling steers kept under permanent grazing in an integrated crop-livestock system. The treatments consisted of areas with sward heights of 10;20;30 and $40 \mathrm{~cm}$, and one treatment with no grazing. The pastures were of bristle oat (Avena strigosa Schreb.) and annual ryegrass (Lolium multiflorum Lam.) following soybean (Glycine max (L.) Merr.). The variables forage mass, forage allowance and residual straw showed a positive and linear fit to the increasing sward height $(\mathrm{P} \leq 0.0001)$. Average daily gain of steers displayed a quadratic response $(\mathrm{P}=0.0017)$, being optimal with increases in grazing height up to values of near $30 \mathrm{~cm}$, showing a weight gain per animal of approximately $1.0 \mathrm{~kg} \mathrm{day}^{-1}$. A similar response was seen for live weight at slaughter and carcass characteristics $(\mathrm{P} \leq 0.0305)$. The results suggest that sward heights close to $30 \mathrm{~cm}$ provide greater individual gains, due to the increase in forage available to each animal and the better quality of the consumed forage without compromising the residual straw destined for the following crop.
\end{abstract}

Key words: Steers. Pasture-management. Animal stock. Average daily gain. Carcass weight.

RESUMO - O objetivo deste trabalho foi avaliar o efeito de diferentes intensidades de pastejo sob a produção de forragem e o desempenho animal de novilhos superprecoces mantidos sob pastejo contínuo em sistema integrado de produção agropecuária. Os tratamentos consistiram das alturas de manejo de pasto de 10;20; 30 e $40 \mathrm{~cm}$; e de um tratamento sem pastejo. Os pastos eram constituídos de aveia-preta (Avena strigosa Schreb.) e azevém anual (Lolium multiflorum Lam.) em sucessão a cultura da soja (Glycine max (L.) Merr.). As variáveis massa de forragem, oferta de forragem e palhada residual se ajustaram de forma positiva e linear ao incremento da altura do pasto $(\mathrm{P} \leq 0,0001)$. O desempenho individual de novilhos apresentou resposta quadrática $(\mathrm{P}=0,0017)$ e foi otimizado com o incremento na altura do pasto até valores próximos a $30 \mathrm{~cm}$, com ganho de peso por animal de aproximadamente $1,0 \mathrm{~kg} \mathrm{dia}^{-1}$. O mesmo foi observado para o peso vivo ao abate e as características de carcaça $(\mathrm{P} \leq 0,0305)$. Os resultados sugerem que alturas próximas a $30 \mathrm{~cm}$ permitem maiores ganhos individuais, devido ao aumento da quantidade de forragem disponível por animal e a melhor qualidade da forragem consumida, não havendo comprometimento da palhada residual destinada à cultura subsequente.

Palavras-chave: Novilhos. Pastagem-manejo. Carga animal. Ganho médio diário. Peso de carcaça.

\footnotetext{
DOI: $10.5935 / 1806-6690.20160022$

* Autor para correspondência

'Recebido para publicação em 05/04/2014; aprovado em 12/06/2015

Parte da Dissertação de Mestrado do primeiro autor apresentada ao Programa de Pós-Graduação em Zootecnia - Área de Concentração em Plantas Forrageiras da Universidade Federal do Rio Grande do Sul/UFRGS. Pesquisa financiada com recursos da Fundação Agrisus e CNPq

${ }^{2}$ Departamento de Fitotecnia, Empresa de Pesquisa Agropecuária e Extensão Rural de Santa Catarina, Estação Experimental de Videira, Campo Experimental, Videira-SC, Brasil, 89.560-000, cristianewesp@yahoo.com.br/cristianewesp@epagri.sc.gov.br

${ }^{3}$ Departamento de Plantas Forrageiras e Agrometeorologia, Universidade Federal do Rio Grande do Sul, Campus Agronomia, Agronomia, Porto Alegre-RS, Brasil, 91.540-000, paulocfc@ufrgs.br

${ }^{4}$ Embrapa Soja, Empresa Brasileira de Pesquisa Agropecuária, Transferência de Tecnologia, Distrito de Warta, Londrina-PR, Brasil, 86.001-970, agriconte@gmail.com/osmar.conte@embrapa.br

${ }^{5}$ Departamento de Biometría, Estadística y Computación, Universidad de La República, Facultad de Agronomía, Montevideo-UY, Uruguay, mcadenazzi2010@gmail.com

${ }^{6}$ Departamento de Solos, Universidade Federal do Rio Grande do Sul, Campus Agronomia, Agronomia, Porto Alegre-RS, Brasil, 91.540-000, ibanghi@ufrgs.com ${ }^{7}$ Divisão de Pesquisa e Inovação Tecnológica, Fundação Estadual de Pesquisa Agropecuária, Sede, Menino Deus, Porto Alegre-RS, Brasil, 90.130-060, carolina_bremm@viavale.com.br/carolina-bremm@fepagro.rs.gov.br
} 


\section{INTRODUCTION}

The use of cover crops to feed livestock makes the economic stability and sustainability of no-tillage integrated crop-livestock systems (ICL-NT) possible. The existence of grazing cattle in these systems improves the efficiency of the land use and alters the dynamics of nutrient cycling in the soil, and if grazing intensity is properly managed, it will promote the subsequent grain crop (FRANZLUEBBERS, 2007; SULC; TRACY, 2007; TRACY; ZANG, 2008).

Grazing intensity (GI) is a fundamental variable for grassland management. It is ultimately under human control and defined by the rate of animal stock and its distribution over space and time (e.g. resting periods defined for rotational stocking). Therefore, GI has a direct influence on forage weight, growth rate and sward height, being described as the major biotic factor, affecting the quantity and quality of available forage in a pastoral environment (FRANZLUEBBERS; SEMAN; STUEDEMANN, 2013). The GI consequently influences forage intake per animal and per area (CARVALHO et al., 2010). Data in the literature support the suggestion that, when high grazing intensities are used, the animal intake rate is higher than the forage growth rate. As a consequence, the grazing animal increases the number of feeding stations visited in response to the restricted forage allowance (BAGGIO et $a l .$, 2008). In such a situation, grazing animals have higher energy costs, which result in limited performance and affects carcass characteristics when destined for finishing and slaughter (LOPES et al., 2008).

Grassland management under ICL, however, should be seen as an essential tool for building a pasture structure that can optimize the harvesting of forage by the grazing animal. Targeting suitable pasture structures can influence positively animal production and residual straw, the latter in order to maintain soil quality and assure the establishment of subsequent crops (CARVALHO et al., 2010). The objective of this study, therefore, was to evaluate the effects of grazing intensities by managing pasture heights in a mixture of bristle oat and annual ryegrass grown following a soybean crop. Forage production, animal performance and carcass characteristics in steers aged 10 to 14 months were assessed in a typical integrated crop-livestock system in the south of Brazil.

\section{MATERIAL AND METHODS}

\section{Site description and experimental design}

The study site is located in São Miguel das Missões, in the state of Rio Grande do Sul, Brazil, on Espinilho
Farm (28 $56^{\prime} 14.00^{\prime \prime}$ S, 54 $20^{\circ} 45.61^{\prime \prime}$ W; at an altitude of $465 \mathrm{~m}$ ). The area has been managed under NT since 1993. In 2001, approximately 22 ha of the farm were converted into an experimental area under a system that integrates grain crops with beef cattle produced on the same unit of land. Since then, soybean has been rotated with mixtures of bristle oat (Avena strigosa Schreb.) and annual ryegrass (Lolium multiflorum Lam), in an ICL-NT focused on the grazing of animals for fattening and slaughter.

The mean annual temperature is $17.1^{\circ} \mathrm{C}$ with a mean annual rainfall of $1.767 \mathrm{~mm}$. According to the Köppen classification, the climate is defined as Cfa, subtropical humid. The soil is classified as Rhodic Hapludox (Oxisol, $0.54 \mathrm{~kg} \mathrm{~kg}^{-1}$ clay, $0.17 \mathrm{~kg} \mathrm{~kg}^{-1}$ silt and $0.29 \mathrm{~kg} \mathrm{~kg}^{-1}$ of sand, 0-20 cm), being deep and well drained. The soil chemical characteristics were as follows: $10.5 \mathrm{mg} / \mathrm{dm}^{-3}$ phosphorus, $94 \mathrm{mg} \mathrm{dm}^{-3}$ potassium, $3.2 \mathrm{cmolc} \mathrm{dm}^{-3} \mathrm{Al}^{3+}$, $34 \mathrm{~g} \mathrm{~kg}^{-1}$ organic matter and $\mathrm{pH}$ of 4.3 (in water).

The treatments comprised different sward heights: $10,20,30$ and $40 \mathrm{~cm}$. A non-grazed area was used as the control (NG). The experimental design was a completely randomised block with three replicates of the sward height (grazed treatments), and two replicates of the NG. Then, there were 14 experimental units totalling 21 ha (paddocks from 0.8 to 3.6 ha). In order to maintain the desired sward height, put-and-take stocking was utilized with adjustments made in the stocking rate at 15-days intervals, using the variable stocking rate method proposed by Mott and Lucas (1952). Yet, three tester animals were continuously stocked in each paddock, with a variable number of 'put and take' animals.

After soybeans were harvested in May 2008, black-oat cv. IAPAR 61 was sown in rows, seeding rate at $100 \mathrm{~kg} \mathrm{ha}^{-1}$. Annual ryegrass establishment originate from natural reseeding from previous years. The pasture was fertilized with simple superphosphate at a rate of $300 \mathrm{~kg}$ $\mathrm{ha}^{-1}$ at planting. Nitrogen was applied as urea (45 kg N ha$\left.{ }^{1}\right)$ when black-oat was tillering. Animals started grazing on July $17^{\text {th }}$, when pasture reached an average sward height of $28 \pm 3.6 \mathrm{~cm}$ and a forage mass of $1700 \pm 216.0 \mathrm{~kg}$ dry matter $\left(\mathrm{kg} \mathrm{DM} \mathrm{ha}^{-1}\right)$. During the grazing cycle, 81 steers were used. Of this total, 36 steers constituted the tester animals, which remained on pasture throughout all the experimental period. A cross between Angus, Hereford and Nellore castrated steers aging 10 months, weighting $203 \pm 1.7 \mathrm{~kg}$ and with initial body condition score (BCS) of $3.47 \pm 0.02$ was used. The grazing cycle lasted 122 days, until November $15^{\text {th }}$, when the animals were conducted to slaughter.

\section{Sward measurement}

Sward height was monitored every 15 days, using a sward stick (BARTHRAM, 1985). This monitoring was 
carried out randomly by reading 100 sampling points per paddock in a "W" course in order to compose the average sward height $(\mathrm{SH}, \mathrm{cm})$ for each experimental unit. Estimates of forage mass (FM, $\mathrm{kg} \mathrm{DM} \mathrm{ha}^{-1}$ ) were monthly performed, using the double sampling technique (WILM; COSTELLO; KLIPPLE, 1944). Five cuts were randomly assessed in an area of $0.25 \mathrm{~m}^{-2}$, in each experimental unit. Daily forage accumulation rate (DM, kg DM ha-1) was monitored monthly, using three grazing exclusion cages in each experimental unit (KLINGMAN; MILES; MOTT, 1943). All samples were cut at ground level.

Samples were dried at $65^{\circ} \mathrm{C}$ until constant weight. They were crushed in a grinder type "Willey", using a 1 $\mathrm{mm}$ sieve and sent for analysis of crude protein (CP), crude fiber $(\mathrm{CF})$ and neutral detergent fiber (NDF), according to the Association of Official Analytical Chemists (1984). The content of total digestible nutrients (TDN) was estimated according to Barber, Adamson and Altman (1984).

Forage allowance (FA, kg DM kg-1 body weight day $^{-1}$ ) was expressed by the ratio between available forage and stocking rate, according to Sollenberger et al. (2005). Sward structural components were assessed by morphological separation of forage mass cuts. Once separated, these fractions were dried at 65 ${ }^{\circ} \mathrm{C}$ until reaching constant weight. By estimating sward structural components proportion, the estimated leaf blade mass (BLM) was obtained for the entire grazing period. Leaf blade forage allowance (BLA) was estimated as previously describe to FA. Total forage production (TFP, $\mathrm{kg} \mathrm{DM} \mathrm{ha}{ }^{-1}$ ) was estimated by the sum of sward production assessed monthly (accumulation rate $\mathrm{x}$ number of days in the sub-period) in addition to the pre-grazing forage mass. In the last grazing period, after removing the animals, the residual straw (RS, $\mathrm{kg} \mathrm{DM} \mathrm{ha}{ }^{-1}$ ) was evaluated in all treatments. All plant biomass on the ground was collected in the forage mass cutting sites.

\section{Animal measurement}

The average daily gain (ADG, $\mathrm{kg}$ animal ${ }^{-1}$ ) of the tester animals during the entire grazing period was evaluated by performing two weighings at the beginning and the end of the experimental period. Animals were fasted prior of 12-h. The difference between the initial and final weight were divided by the total number of days spent in grazing originating ADG. The stocking rate (SR, $\mathrm{kg}$ live weight $^{-1}$ ha $^{-1}$ ) during the grazing period was calculated by adding the average live weight of tester animals with the average live weight of each 'put and take' animal multiplied by the number of days they remained in the pasture, and then, divided by the total number of grazing days. The live weight gain per hectare (LWG, $\mathrm{kg} \mathrm{ha}^{-1}$ ) was obtained by multiplying the average SR by ADG. Body condition score (BCS) was visually assigned at the initial and final steers weightings according to Lowman, Scott and Somerville (1973), using the scale 1.0 (very thin) to 5.0 (very fat).

Carcasses results presented were obtained by the average values of nine tester animals slaughtered of treatment, in a total of 36 animals. They were identified, washed, and weighed to obtain the hot carcass weight (HCW), and then cooled to $-2{ }^{\circ} \mathrm{C}$ for 24 hours. After the chilling period, carcasses were weighed again to determine the following parameters: cold carcass weight $(\mathrm{CCW})$, forequarter weight $(\mathrm{FW})$, posterior weight $(\mathrm{PW})$ and side cut weight (SW). All these cuts were expressed on a percentage basis (yield): cold carcass yield (CCY), forequarter yield (FY) side cut yield (SY) posterior yield (PY), thus encompassing the main commercial cuts.

\section{Statistical analyses}

The data were subjected to analysis of variance at $5 \%$ level of significance. When detecting differences among treatments, means were compared by Tukey Test at 5\% significance, using the Mixed procedure of SAS software (SAS INSTITUTE, 2001). Polynomial regressions were performed at $5 \%$ level of significance. The response variables were regressed on the actual sward height measured. When the response function was significant $(\mathrm{P}<0.05)$, the regression equation with the higher coefficient of determination $\left(\mathrm{R}^{2}\right)$ was used. The correlation between response-variables was performed by using the Corr procedure of SAS (SAS INSTITUTE, 2001). To identify sward variables (independent) with greatest influence on animal performance (dependent), besides $\mathrm{R}^{2}$, the Akaike information criterion (AIC) of SAS were performed, selecting the best model according to the lowest AIC value.

\section{RESULTS AND DISCUSSION}

\section{Sward parameters}

Actual sward heights were $14.1 ; 22.6 ; 32.0$ and $41.1 \pm 3.2 \mathrm{~cm}$, for $10 ; 20 ; 30$ and $40 \mathrm{~cm}$ respectively. NG sward height was $45.0 \pm 2.0 \mathrm{~cm}$ and did not differ from the lowest grazing intensity treatment $(40 \mathrm{~cm})$. Differences were found when grazed treatments were contrasted $(\mathrm{P}<0.0001)$, endorsing that desired differences among treatments were achieved.

Forage mass (FM; $r=0.97)$, leaf blade mass (BLM; $r=0.93)$, forage allowance $(F A ; r=0.96)$ and leaf blade allowance (BLA; $r=0.95)$ showed high correlation with SH $(\mathrm{P}<0.0001)$. FM and BLM were linearly related to sward height $(\mathrm{P}<0.0001)$. FM registered were 2.441; $3.316 ; 3.810 ; 4.517$ and $5.444 \pm 300 \mathrm{~kg} \mathrm{DM} \mathrm{ha}^{-1}$, while the 
BLM averages were equal to $1.056 ; 1.182 ; 1.135 ; 1.446$; $1.483 \pm 53 \mathrm{~kg} \mathrm{DM} \mathrm{ha}^{-1}$ for treatments $10 ; 20 ; 30 ; 40 \mathrm{~cm}$, and NG, respectively (Figure 1).

FA $\left(\mathrm{Y}=-3.80+0.36 \mathrm{x}, \mathrm{R}^{2}=0.9254, \mathrm{SD}=\right.$ $1.19, \mathrm{P}<0.0001)$ and $\mathrm{LBA}\left(\mathrm{Y}=-0.93+0.11 \mathrm{x}, \mathrm{R}^{2}=\right.$ $0.9053, \mathrm{SD}=0.40, \mathrm{P}<0.0001)$ also increased linearly with increasing sward heights. Daily FA averages were 1.77; 3.65; 5.84; $11.68 \pm 1.24 \mathrm{~kg} \mathrm{DM}^{-1} \mathrm{~kg} \mathrm{BW}^{-1}$, while daily BLA averages were $0.77 ; 1 ; 1.72$; and $3.74 \pm 0.37$ $\mathrm{kg} \mathrm{DM}^{-1} \mathrm{~kg} \mathrm{BW}^{-1}$, from high to low intensity grazing, respectively.

The strong correlation found among SH and FM, FA, BLM and BLA indicates that, under controlled conditions of pasture management, sward height can be a worthy indicator of the amount of available forage. Sward height assessments can be performed quickly and provide easiness in data collection. As soon as it is properly calibrated, it describes accurately the vertical dimension of FM (MANNETJE, 2000).

According to Stewart Júnior et al. (2007), forage mass and herbage allowance tend to decrease ou increasing) grazing intensities. Registered FM and FA results in this study support this statement. The increase observed in FM increasing with the increase of $\mathrm{SH}$, confirms previous results obtained by Aguinaga et al. (2008); Baggio et al. (2008) and Lopes et al. (2009). Moreover, FM increased $85.4 \mathrm{~kg} \mathrm{DM} \mathrm{ha}^{-1}$ for each $\mathrm{cm}$ increase in sward height, which was similar to $86.3 \mathrm{~kg} \mathrm{DM}^{-1}$ ha presented by Aguinaga et al. (2008).

Drescher et al. (2006) stated that forage selection by grazing animals is related to the availability and accessibility of leaf blades within grazing horizons. The high correlation found between BLM and SH, and the adjustment of this variable to a linear regression model indicates an increase in the participation of this component in pasture structure with the increase of sward heights. Maintaining FM with high proportion of leaf blade is desirable, as they play a dual role in the plantanimal interface. It represents the surface responsible by light interception and plant growth, as well as the higher quality item in animal diet (LEMAIRE; AGNUSDEI, 2000). The increment of $14 \mathrm{~kg} \mathrm{DM} \mathrm{ha}^{-1} \mathrm{BLM}$ at every $\mathrm{cm}$ in $\mathrm{SH}$ was similar to $13.7 \mathrm{~kg} \mathrm{DM} \mathrm{ha}^{-1}$ previously reported by Baggio et al. (2008). These data reinforce the observation of Pontes et al. (2004), that, at low grazing intensities, as maturing tillers become reproductive, they no longer produce new leaves. Therefore, the rate of leaf appearance tends to decrease $\mathrm{SH}$ due to the increase in sheath length of successive leaves. This would result in greater length of leaf blades, small number of leaves per tiller and, consequently, low tillering (DRESCHER et $a l .$, 2006). With regard to FA and BLA variables, they increased linearly with the increase of SH. This response corroborates with the results obtained in previous studies (BAGGIO et al., 2008; LOPES et al., 2008).

High negative correlation was observed between the crude protein $(\mathrm{CP})$ and $\mathrm{SH}(\mathrm{r}=-0.84 ; \mathrm{P}=0.0002)$, FM $(\mathrm{r}=-0.83 ; \mathrm{P}=0.0004)$, BLM $(\mathrm{r}=-0.81 ; \mathrm{P}=$ $0.0008)$, FA ( $\mathrm{r}=-0.91 ; \mathrm{P}<0.0001)$ and BLA ( $\mathrm{r}=-0.89$; $\mathrm{P}=0.0002)$. Both crude fiber $(\mathrm{CF})$ and the neutral detergent fiber (NDF) were positively correlated with SH $(\mathrm{P} \leq 0.0116), \mathrm{FM}(\mathrm{P} \leq 0.0280)$ and $\mathrm{BLM}(\mathrm{P} \leq 0.0385)$. The correlation between NDF and FA $(\mathrm{P}=0.0171)$, and BLA $(\mathrm{P}=0.0212)$ was observed. Thus, there was a linear increase of $\mathrm{CF}\left(\mathrm{Y}=223.91+2.22 \mathrm{x}, \mathrm{R}^{2}=0.7267, \mathrm{SD}=\right.$ $15.83, \mathrm{P}=0.0017)$ and $\mathrm{NDF}=\left(\mathrm{Y}=556.84+2.70 \mathrm{x}, \mathrm{R}^{2}\right.$ $=0.7459, \mathrm{SD}=18.14, \mathrm{P}=0.0013)$ with the increase of sward heights. There was no correlation between the total digestible nutrients (TDN) and the variables associated with pasture characterization. However, there was a quadratic effect of this variable with the increase of sward heights $\left(\mathrm{Y}=521.29+6.98 \mathrm{x}-0.12 \mathrm{x}^{2} ; \mathrm{R}^{2}=\right.$ $0.7626 ; \mathrm{SD}=8.26 ; \mathrm{P}=0.0032)$.

Figure 1 - Relationship between sward height (cm), forage mass $\left(\mathrm{kg} \mathrm{ha}^{-1}\right.$ of DM) and leaf blade mass (BLM, $\mathrm{kg} \mathrm{ha}^{-1}$ of DM), in black oat and annual ryegrass pastures managed under different sward heights, following the soybean
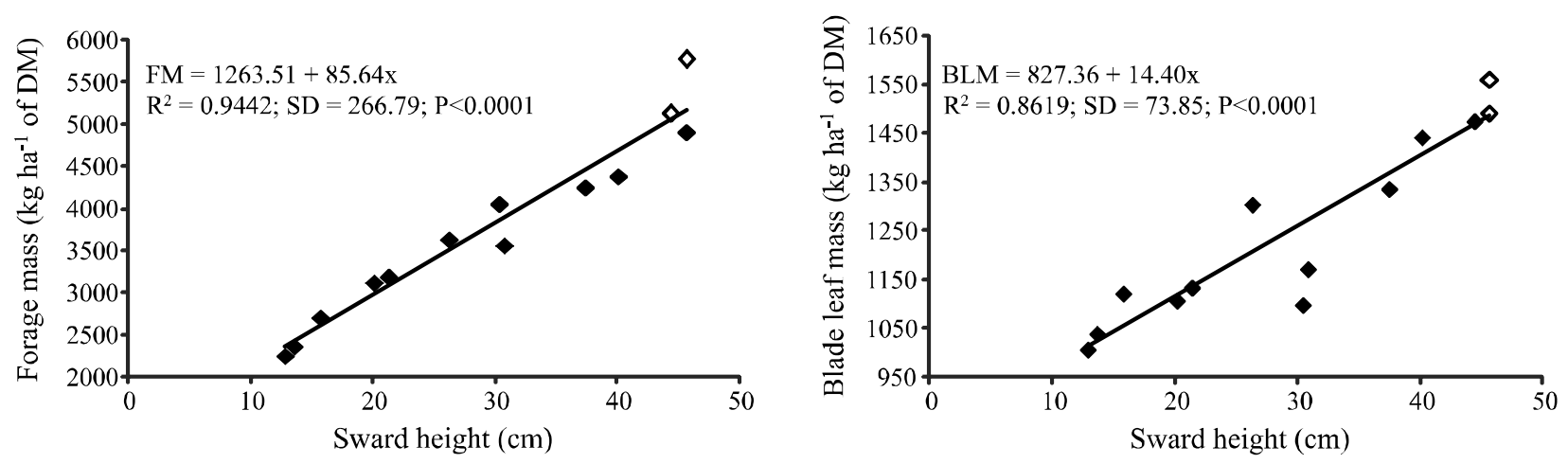
The daily accumulation rate (DAR) was linearly related to sward height $\left(\mathrm{Y}=17.72+1.40 \mathrm{x}, \mathrm{R}^{2}=\right.$ $0.7098, \mathrm{SD}=10.24, \mathrm{P}=0.0006)$. The registered DAR for 20 and $40 \mathrm{~cm}$ ranged from 37 to $78 \pm 4.5 \mathrm{~kg} \mathrm{ha}^{-1}$ DM, respectively. Total forage production (TFP) showed a quadratic effect with the increase of sward height $\left(\mathrm{Y}=1.1487-448.615 \mathrm{x}+7.586 \mathrm{x}^{2} ; \mathrm{R}^{2}=0.7180 ; \mathrm{SD}=\right.$ $555.74 ; \mathrm{P}=0.0034)$, where values ranged from 4.495 to $6.623 \pm 244 \mathrm{~kg} \mathrm{ha}^{-1} \mathrm{MS}$ for treatments of 30 and $10 \mathrm{~cm}$, respectively. The residual straw (RS) was correlated with $\mathrm{SH}, \mathrm{FM}, \mathrm{BLM}, \mathrm{FA}$ and BLA $(\mathrm{P}<0.05)$. There was a linear increase in RS increasing sward height $(\mathrm{P}=0.0001)$. Values ranged from 979 to $5,412 \pm 398 \mathrm{~kg} \mathrm{ha}^{-1} \mathrm{DM}$, from the lower $\mathrm{SH}$ to the non-grazed treatment. An increase of $107 \mathrm{~kg} \mathrm{ha}^{-1} \mathrm{DM}$ was observed for each $\mathrm{cm}$ increase in sward height. There was also a positive correlation between FM and BLM, FA, BLA and RS $(\mathrm{P}<0.0001)$.

\section{Animal parameters}

ADG fitted to a quadratic response increasing $\mathrm{SH}$ $(\mathrm{P}=0.0017)$. There was an increase in individual animal performance up to $33 \mathrm{~cm} \mathrm{SH}$, where estimated ADG was $0.97 \mathrm{~kg}$ animal ${ }^{-1}$. LWG decreased linearly with the increase of $\mathrm{SH}(\mathrm{P}<0.0001)$, values ranging from 495 to $156 \mathrm{~kg} \mathrm{ha}^{-1}$ for 10 and $40 \mathrm{~cm}$, respectively. SR decreased linearly $(\mathrm{P}<0.0001)$ at a rate of $34 \mathrm{~kg} \mathrm{ha}^{-1} \mathrm{LW}$ at every $\mathrm{cm}$ increment in SH. The SR, at the lowest SH, was 3.6 times superior when compared to that experienced in the highest SH (Figure 2).

A negative correlation was found between $\mathrm{SR}$ and $\mathrm{FM}(\mathrm{r}=-0.96 ; \mathrm{P}<0.0001), \mathrm{FA}(\mathrm{r}=-0.92 ; \mathrm{P}<0.0001), \mathrm{BLM}$ $(\mathrm{r}=-0.79 ; \mathrm{P}=0.0037)$, BLA $(\mathrm{r}=-0.90 ; \mathrm{P}=0.0002)$ and ADG $(r=-0.82 ; P=0.0036)$. The $\mathrm{SR}$ was also positively correlated with the LWG $(r=0.90 ; \mathrm{P}<0.0001)$.

To better understand registered animal responses, variables related to forage allowance and sward structure were utilized as independent variables for ADG, LWG and SR models (Table 1).

The model obtained for the ADG shows that $92 \%$ of variation was explained by the BLA, indicating the importance of this parameter in grazing experiments. Concerning the LWG, the variation was explained by the SH in $84 \%$, confirming that the management of this variable has great importance when the objective is the animal gain per area. The $\mathrm{SH}$ was also primarily responsible for the variation in SR, accounting for $90 \%$ of the variation found in this variable.

A quadratic response was observed for live weight (LW) with the increase of the sward height $(\mathrm{P}=0.0302)$. As it increased, there was an increase in $\mathrm{LW}$ up to $31 \mathrm{~cm}$, where the LW estimated of $338.6 \mathrm{~kg}_{\text {animal }}{ }^{-1}$.

Figure 2 - Relationship between sward height $(\mathrm{cm})$, average daily gain $\left(\mathrm{kg}_{\text {animal }}{ }^{-1}\right)$, live weight gain $\left(\mathrm{kg} \mathrm{ha}^{-1}\right)$ and stocking rate $\left(\mathrm{kg} \mathrm{ha}^{-1} \mathrm{LW}\right)$ in oat and ryegrass mixtures managed under different sward heights
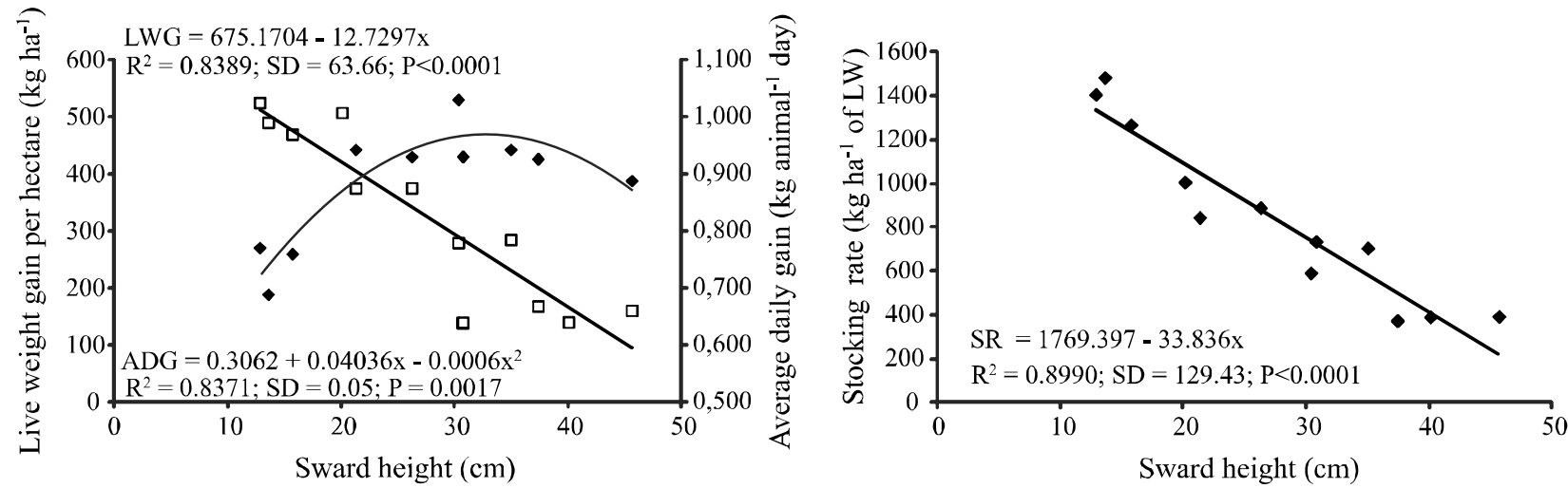

Table 1 - Regression models used for animal performance of beef steers grazing oat and ryegrass mixtures managed under different sward heights

\begin{tabular}{lcccc}
\hline$\hat{y}$ & Regression model & AIC & $\mathrm{R}^{2}$ model & Pr $>\mathrm{F}$ \\
\hline ADG & $0.43+0.48 \mathrm{OFL}-0.09 \mathrm{BLA}^{2}$ & -14.2 & 0.9199 & 0.0005 \\
LWG & $675.17-12.73 \mathrm{SH}$ & 123.1 & 0.8388 & $<0.0001$ \\
SR & $1769.40-33.84 \mathrm{SH}$ & 137.3 & 0.8990 & $<0.0001$ \\
\hline
\end{tabular}

ADG: Average daily gain $\left(\mathrm{kg}\right.$ animal $\left.^{-1}\right)$; LWG: live weight gain per hectare $\left(\mathrm{kg} \mathrm{ha}^{-1}\right)$; SR: Stocking rate $\left(\mathrm{kg}\right.$ bodyweight $\left.^{-1} \mathrm{ha}^{-1}\right)$; $\mathrm{SH}$ : Sward height (cm); BLA: Daily leaf blade allowance ( $\mathrm{kg} \mathrm{DM} \mathrm{kg}^{-1}$ body weight) 
Final BCS accompanied the quadratic response of ADG and LW, with the increase of the $\mathrm{SH}$ until $32 \mathrm{~cm}$; and the final estimated BCS was 4.1 points. $\mathrm{HBW}$ and $\mathrm{CBW}$ also fitted a quadratic model, maximum values being 168.3 and $173.2 \mathrm{~kg}$ for $\mathrm{SH}$ of 33 and $32 \mathrm{~cm}$, respectively. All primary cuts weight were adjusted to a quadratic model. FW had estimated maximum value of $67.9 \mathrm{~kg}$ for SH of 31 $\mathrm{cm}$, whist SW and PW increasing with the increase of the sward height up to $33 \mathrm{~cm}$, with estimated values of 23.1 and $86.4 \mathrm{~kg}$, respectively.

The animals showed a CCY average of $53.5 \%$. The CCW did not fit the quadratic model, but showed the same stabilization trend with slightly decrease from the $30 \mathrm{~cm}$ height $(55 \pm 0.47 \%)$. Mean values expressed when percentage of carcass were $38.5 ; 12.7$ and $48.8 \%$ for FY, SY, PY, respectively. Both SY (Y $=7.961-0.356 \mathrm{x}+$ $\left.0.006 \mathrm{x}^{2} ; \mathrm{R}^{2}=0.6031 ; \mathrm{SD}=0.63 ; \mathrm{P}=0.0248\right)$ and $\mathrm{PY}(\mathrm{Y}$ $=44.243-0.316 \mathrm{x}-0.004 \mathrm{x}^{2} ; \mathrm{R}^{2}=0.7850 ; \mathrm{SD}=0.47 ; \mathrm{P}=$ $0.0046)$ adjusted to a quadratic model.

The results obtained for the ADG and LW are explained because herbivores are faced with complexes situations when the diet selection occurs in pastures with advanced reproductive stages, which was evidenced by the stabilization, and even decrease, of the ADG registered in the treatment of $40 \mathrm{~cm}$. Leaf blades and stems are in very close contact when annual pastures are tall and mature, which causes a reduction in the accessibility of leaves, since the stems represent a barrier to gather a bite (GORDON;BENVENUTTI, 2006).

According to Sollenberger and Moore (1997), daily forage allowances below $1.0 \mathrm{~kg} \mathrm{DM}^{-1} \mathrm{~kg}^{-1} \mathrm{LW}$ are generally associated with constraining forage intake, which leads to an animal performance impairment. Thus, the lowest ADG achieved in $10 \mathrm{~cm}$ is explained by the consequential limited forage consumption occurred, as observed daily BLA was below reference (0.77 $\left.\mathrm{kg} \mathrm{DM}^{-1} \mathrm{~kg}^{-1} \mathrm{BW}\right)$.

The increasing values for the FM, BLM, FA and BLA with the increase of the SH may be attributed to the lowest SR used in treatments conducted under lower grazing intensities. This response was clearly evidenced by the high correlation between these variables. The same pattern was already describe assessing the effect of grazing intensities on forage production, where higher grazing intensities decreased FM and FA (HERNÁNDEZ GARAY et al., 2004; INYANG et al., 2010). Consequently, increasing grazing intensities directly influences animal performance due to the lowest forage availability (AGUINAGA et al., 2008). Coleman and Sollenberger (2007) stated that animal production is directly related to the percentage of leaves on offer to the animal, and the digestibility of the forage consumed. According to Lemaire and Agnusdei
(2000), what determine the amount of forage consumed and the proportions of each component in that amount is the plant chemical composition, the ease of apprehension, and the leaf proportion of the pasture.

Although the obtained results on nutritional value showed higher crude protein content in the highest grazing intensities, the ADG results show lower gain per animal. Conversely, the higher levels of CF and NDF with the increase o the of $\mathrm{SH}$ were not sufficient to restrict the animal performance. These results illustrates that forage quality can became a bad predictor of animal performance on grazing situations where the $\mathrm{SH}$ is preponderant to define their intake (CARVALHO, 2013). Thus, in the SH about 30 $\mathrm{cm}$, the highest animal performance is due to a better sward structure to gather high bite masses having opportunity to exert diet selection. Drescher et al., (2006) observed that the amount of green leaves had great influence on the animal performance. Therefore, the $\mathrm{SH}$ is an important parameter, reflecting the accessibility of forage (leaves) for grazing animals. Yet, the slightly decrease in the ADG at $40 \mathrm{~cm}$ suggest that increases in height and herbage mass are not desirable beyond a critical point sufficient to ensure high profits (COLEMAN; SOLLENBERGER, 2007). According to Gordon and Benvenutti et al. (2006), advances in the animal production will be obtained by keeping pastures with green leaves in accessible surface horizons, which agrees with the previously reported influence of the BLA on the ADG.

The positive correlation found between the ADG, $\mathrm{SH}$ and FM demonstrates that the increase in the amount of forage available, both in height (structure) and mass (quantity), favoured the performance of grazing animals heights about $30 \mathrm{~cm}$. This is consistent with the classic functional response reviewed by Carvalho (2013), where any herbivore has their consumption increased by increasing the amount of available forage, until a stabilization point represented by the saturation of the animal in food processing.

The negative correlation obtained between the AGD, LWG and SR indicates that the highest is the SR, the lowest is the ADG and the highest is the LWG. Lower ADG at high SR are partly due to the decrease in forage allowance and forage mass (HERNÁNDEZ GARAY et al., 2004), resulting in less chance of diet selection. Moreover, the LWG classically tends to increase when high stocking rates are used unless huge constrains in individual animal intake are experienced (CARVALHO et al., 2010; INYANG et al., 2010). Thus, the SR can be considered a crucial parameter that affects grazing cattle performance (INYANG et al., 2010). This statement was evidenced in this study, mainly by the high negative correlation obtained between the SR and FM, FA, BLM, BLA. In conclusion, $\mathrm{SH}$ would not be over $30 \mathrm{~cm}$, because of the negative 
impact in the ADG and LWG. Conversely, it would not approach $10 \mathrm{~cm}$ as the ADG drops significantly despite increasing the LWG. This creates a range of SH between 20 and $30 \mathrm{~cm}$ that can be used to accomplish different combinations of the ADG and/or LWG goals. Hence, the optimal grazing intensity or targeted $\mathrm{SH}$ to be used in a given production system will depend on the production goals established, considering the relationship between maximum individual animal performance or maximum production per area (CARVALHO et al., 2010).

The results for the $\mathrm{LW}, \mathrm{HCW}$ and $\mathrm{CCW}$ show a similar response pattern as that one for the ADG. The results demonstrate the high potential of beef production on the pasture cycle between soybean crops. Yearling steers can produce high quality carcasses in a small period of time (about 120 grazing days). This could be useful when pastures do not be a part of the ICL system at the same time as crop (e.g. summer annuals).

Regarding productivity, it must be considered that the higher animal production per area obtained in pastures managed at $10 \mathrm{~cm}\left(495 \mathrm{~kg} \mathrm{ha}^{-1} \mathrm{LW}\right)$ can increase the possibility of soil compaction because of higher SR (GEORGE et al., 2013). In addition, it is worth noting that this treatment provided the lowest available forage mass. Conversely, the ICL-NT requires substantial amounts of plant residues in the system. Besides low herbage masses constitute a scenario of food limitation, it represents the amount of plant tissues present between the hoof of the animal and the soil surface (FLORES et al., 2007). In this context, the RS registered at the higher grazing intensity $\left(10 \mathrm{~cm}\right.$ : $\left.979 \mathrm{~kg} \mathrm{ha}^{-1} \mathrm{DM}\right)$ would be far from desirable. According to Flores et al. (2007), since RS reaches close to $2.000 \mathrm{~kg} \mathrm{ha}^{-1} \mathrm{DM}$, soybean yield is not jeopardized in the subsequent cultivation.

Therefore, the management of grazing intensity in the ICL-NT plays a fundamental role in systems function, since it influences both crop and animal production, as well as economic outcomes obtained in system (OLIVEIRA et al., 2013).

\section{CONCLUSIONS}

Yearling steers individual performance in black oat and annual ryegrass pasture is optimized by managing sward height close to $30 \mathrm{~cm}$, which corresponds to a herbage mass around $3.800 \mathrm{~kg} \mathrm{DM} \mathrm{ha}{ }^{-1}$. Live weight gain per area and stocking rate decrease linearly with the increase of the sward height. Carcass characteristics are favoured at the same sward target that promotes better individual animal performance. There is a range to increase animal production per area managing pastures at lower sward heights, but not below $20 \mathrm{~cm}$. Considering a no-till integrated crop-livestock system, animal production during pasture phase should not occur at the expense of soil cover, so pasture targets for typical annual temperate pastures rotating with soybean should stay above $20 \mathrm{~cm}$. The main goal of the production system will ultimately define if pasture targets would approach $20 \mathrm{~cm}$ or $30 \mathrm{~cm}$, benefiting animal performance per area or per head basis, respectively.

\section{ACKNOWLEDGEMENTS}

We thank Cerro Coroado farm for the experimental animals and area. This research was founded by CNPq, and Fundação Agrisus, Brazil.

\section{REFERENCES}

AGUINAGA, A. A. Q. et al. Componentes morfológicos e produção de forragem de pastagem de aveia e azevém manejadas sob diferentes alturas. Revista Brasileira de Zootecnia, v. 37, n. 9, p. 1523-1530, 2008.

ASSOCIATION OF OFFICIAL ANALYTICAL CHEMISTS. Official methods of analysis. 14. ed. Washington, D.C., 1984. $1141 \mathrm{p}$.

BAGGIO, C. et al. Padrões de uso do tempo por novilhos em pastagem consorciada de azevém anual (Lolium multiflorum Lam.) e aveia preta (Avena strigosa Schreb). Revista Brasileira de Zootecnia, v. 37, n. 11, p. 1912-1918, 2008.

BARBER, W. P. B.; ADAMSON, A. H.; ALTMAN, J. F. B. New methods of feed evaluation. In: HARESIGN, W.; COLE, D. J. A. (Ed.) Recent advances in animal nutrition. London: Butterworths, 1984. p. 161-176.

BARTHRAM, G. T. Experimental techniques: the HFRO sward stick. Hill Farming Research Organization/Biennial Report, 1985. p. 29-30.

CARVALHO, P. C. F. et al. Managing pasture animals to achieve nutrient cycling and soil improvement in no-till integrated systems. Nutrient Cycling in Agroecosystems, v. 88, n. 2, p. 259-273, 2010.

CARVALHO, P. C. F. Harry Stobbs Memorial Lecture: Can grazing behavior support innovations in grassland management? Tropical Grasslands - Forrajes Tropicales, v. 1, n. 2, p. 137155, 2013.

COLEMAN, S. W.; SOLLENBERGER, L. E. Plant-herbivore interactions. In: BARNES, R. F.; et al. (Ed.) Forages - The science of grassland agriculture. Ames: Blackwell Publishing, 2007. p. 123-136.

DRESCHER, M. et al. The role of grass stems as structural foraging deterrents and their effects on the foraging behaviour of clattle. Applied Animal Behaviour Science, v. 101, n. 1/2, p. 10-26, 2006. 
FLORES, J. P. C. et al. Atributos físicos e rendimento de soja em sistema plantio direto em integração lavoura-pecuária com diferentes pressões de pastejo. Revista Brasileira de Ciência do Solo, v. 31, n. 4, 771-780, 2007.

FRANZLUEBBERS, A. J. Integrated Crop-Livestock Systems in the Southeastern USA. Agronomy Journal, v. 99, p. 361-372, 2007.

FRANZLUEBBERS, A. J.; SEMAN, D. H.; STUEDEMANN, J. A. Forage dynamics in mixed tall fescue-bermudagrass pastures of the Southern Piedmont USA. Agriculture, Ecosystems and Environment, v. 168 p. 37- 45, 2013.

GEORGE, S. et al. Impact of grazing on soil properties and cotton yield in an integrated crop-livestock system. Soil \& Tillage Research, v. 132, p. 47-55, 2013.

GORDON, I. J.; BENVENUTTI, M. Food in 3D: how ruminant livestock interact with sown sward architecture at bite scale. In: BELS, V. (Ed.). Feeding in domestic vertebrates: from structure to behaviour. CABInternational, 2006. p. 263-277.

HERNÁNDEZ GARAY, A. et al. Nitrogen fertilization and stocking rate affect stargrass pasture and cattle performance. Crop Science, v. 44, n. 4, p. 1348-1354, 2004.

INYANG, U. et al. Forage species and stocking rate effects on animal performance and herbage responses of 'Mulato' and Bahiagrass pastures. Crop Science, v. 50, n. 3, p. 1079-1085, 2010 .

KLINGMAN, D. L.; MILES, S. R.; MOTT, G. O. The cage method for determining consumption and yield of pasture herbage. Journal of American Society of Agronomy, v. 35, p. 739-746, 1943.

LEMAIRE, G.; AGNUSDEI, M. Leaf tissue turn-over and efficiency of herbage utilization. In: LEMAIRE, G.. et al. (Ed.). Grassland ecophysiology and grazing ecology. Wallingford: CAB International, 2000. p. 265-288.

LOPES, M. L. T. et al. Sistema de integração lavourapecuária: desempenho e qualidade da carcaça de novilhos superprecoces terminados em pastagem de aveia e azevém manejada sob diferentes alturas. Ciência Rural, v. 38, n. 1, p. 178-184, 2008.

LOPES, M. L. T. et al. I Sistema de integração lavourapecuária: efeito do manejo da altura em pastagem de aveia preta e azevém anual sobre o rendimento da cultura da soja. Ciência Rural, v. 39, n. 5, p. 1499-1506, 2009.
LOWMAN, B. G.; SCOTT, N.; SOMERVILlE, S. Condition scoring beef cattle. Edinburgh: East of Scotland College of Agriculture, $1973.8 \mathrm{p}$.

MANNETJE, L.' T. Measuring biomass of grassland vegetation. In: MANNETJE, L.'t.; JONES, R. M. Field and laboratory methods for grassland and animal production research. Cambridge: CAB International, 2000. p. 151-178.

MOTT, G. O.; LUCAS H. L. The design, conduct and interpretation of grazing trials on cultivated and improved pastures. In: INTERNACIONAL GRASSLAND CONGRESS, 6., 1952, Pensylvania. Proceedings... Pensylvania: State College, 1952. p 1380-1395, 1952.

OLIVEIRA, C. A. O. et al. Comparison of an integrated crop-livestock system with soybean only: Economic and production responses in southern Brazil. Renewable Agriculture and Food Systems, v. 29, n. 3, p. 1-9, 2013.

PONTES, L. S. et al. Fluxo de biomassa em pastagem de azevém anual (Lolium Multiflorum Lam.) manejada em diferentes alturas. Revista Brasileira de Zootecnia, v. 33, n. 3, p. 529-537, 2004.

SOLLENBERGER, L. E.; MOORE, J. E. Assessing forage allowance-animal performance relationships on grazed pasture. Agronomy Abstracts, p. 140-141, 1997.

SOLLENBERGER, L. E. et al. Reporting forage allowance in grazing experiments. Crop Science, v. 45, n. 3, p. 896-900, 2005.

SAS INSTITUTE. Statistical Analysis System. User's guide statistics. Cary: 2001. 155 p.

STEWART JÚNIOR, R. L. et al. Herbage and animal responses to management intensity of continuously stocked bahiagrass pastures. Agronomy Journal, v. 99, n. 1, p. 107-112, 2007.

SULC, R. M.; TRACY, B. F. Integrated crop-livestock systems in the U.S. corn belt. Agronomy Journal, v. 99, n. 2, p. 335-345, 2007.

TRACY, B. F.; ZHANG, Y. Soil Compaction, Corn Yield Response, and Soil Nutrient Pool Dynamics within a Integrated Crop-Livestock System in Illinois. Crop Science, v. 48, n. 3, p. 1211-1218, 2008.

WILM, H. G.; COSTELLO, D. F.; KLIPPLE, G. E. Estimating forage yield by the double-sampling methods. Journal of American Society of Agronomy, v. 36, n. 3, p. 194-203, 1944. 